\section{BUSINESS ETHICS}

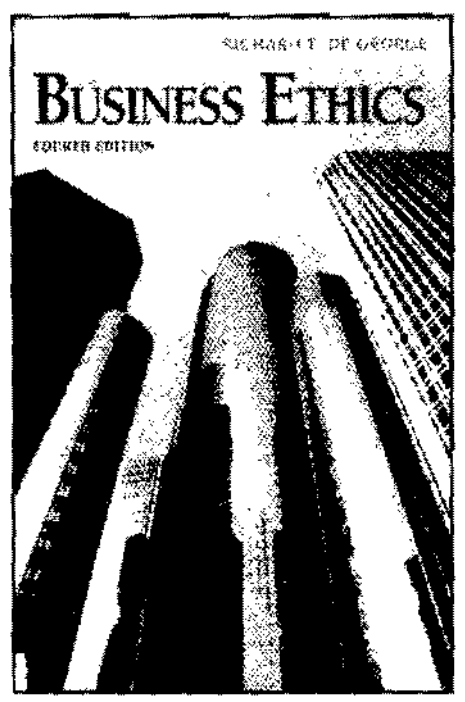

de Richard T. De George

New Jersey: Prentice Hall, 4.ed., 1995, 591 p.

por Paula Csillag, mestranda na área de Organização e Recursos Humanos pela EAESP/FGV.

leitura desse texto de Richard T, De George, chamado carinhosamente de "tijolão" pelos alunos de cursos sobre ética empresarial, não somente é muito agradável (aos que se sentem atraídos pelo assunto), como também apresenta grande fluidez. Estruturado em quatro partes, com os respectivos títulos de: Introdução, Argumentação Moral nos Negócios, Assuntos Morais nos Negócios e Conclusão, o livro possui um caráter bem didático. Cada capítulo é iniciado com a apresentação de um caso prático e finalizado com perguntas para discussão (aspecto tipicamente norte-americano). Não somente as estruturas do livro como um todo e a dos, capítulos individuais são bem elaboradas, como também a do próprio texto, sendo que cada parágrafo apresenta a estrutura propriamente dita de uma dissertação: com sua frase introdutória contendo tópico frasal, com corpo argumentativo e frase conclusiva. Esse fato chamou a atenção, dado que tantos livros lidos em cursos de pós-graduação são extremamente indigestos, por vezes rebuscando a linguagem o máximo possível, com a duvidosa e embutida idéia de que quanto mais difícil a linguagem, mais complexo e profundo deve ser o estudo (?!).

Professor da Universidade de Kansas, De George constata que os cursos sobre ética existem há muito tempo nas faculdades norte-americanas, sendo os de Ética Empresarial bem mais recentes, mas já muito bem consolidados nos cursos de administraçăo e programas de MBA. Ele justifica isso pela era pós-Watergate, com os vários casos notórios ocorridos na época, tais como vendas de produtos com defeitos, quedas de avióes, práticas de suborno e contribuiçôes políticas ilegais.

De George deixa bem claro, na Introdução, os objetivos e pressupostos do seu livro. Em primeiro lugar, pretende apresentar técnicas de argumentação moral necessárias para a análise de questōes éticas nos negócios, seguindo com a abordagem de questões básicas sobre a moralidade dos sistemas econômicos (com um enfoque maior no sistema norte-americano) e terminando por discutir assuntos especificos de administraçäo, com questöes internas a uma empre$s a$, além de questôes externas, nacionais e internacionais.

$\mathrm{O}$ autor pressupöe que, em assuntos sociais amplos, nenhum argumento será final. Ele espera que os alunos, ao lerem seu texto, sintam-se encorajados a continuar o debate público a respeito dos assuntos em questão. Ele pretende discutir não somente o que é moralmente exigido de uma pessoa numa empresa, mas também, como seu enfoque principal, quais estruturas favorecem a aceitação e o cumprimento de uma responsabilidade moral nas empresas.

De George passa em seguida para a segunda parte, intitulada Argumentação Moral nos Negócios. Nessa parte, ele explora um tema muito interessante, tratado por ele como "O Mito da Amoralidade nos Negócios". De acordo com o mito, as empresas agem sem levar em conta a ética (amoral e não imoralmente) näo por seu desejo de fazer o mal, mas simplesmente por quererem ter lucro, ignorando, portanto, algumas consequiências de seus atos. 
De George defende a idéia de que esse mito representa não somente o que a sociedade norte-americana pensa a respeito dos negócios, mas também o que quer pensar. Isso porque, segundo ele, e muito mais trabalhar com números e dólares do que com julgamentos de valor, e muitos gerentes têm dificuldades para lidar com isso.

A partir da exploração desse mito, que oculta grande parte da realidade como ela $e$, o autor passa a outros temas. Inicia fazendo uma análise do sistema de valores americano, passa em seguida a um exame da relação dos Negócios com a Moralidade, para chegar a uma análise da disciplina de Ética e sua relação com a disciplina da Ética Empresarial.

Refere-se a esta ültima basicamente de duas maneiras, à disciplina de Ética nos Negócios entendida dentro da disciplina de Ética e ao que pode ser chamado de Movimento da Ética nos Negócios. Esse movimento iniciou-se nos anos 60 , com a contracultura, a Guerra do Vietnã, a emissão de quantidades crescentes de poluição e os conseqüentes ataques da sociedade às empresas. Assim, estas começaram reagindo à opinião pública por meio de conferências promovidas por grupos como a Câmara de Comércio. Nessa época, o próprio termo Ética nos Negócios era tratado como um oxímoro, uma contradição em si. Mesmo assim, o movimento continuou crescendo, trazendo a ética nos negócios para as escolas de administração e altas cúpulas empresariais, como vemos hoje. Há críticas contra esse movimento: será que ele conseguiu fazer as empresas mais éticas? Será que as empresas manipularam o movimento em seus próprios interesses? Os treinamentos em ética empresarial motivam e ensinam os funcionários a agir eticamente? Entretanto, como coloca De George, o movimento tem a sua validade por ter tornado possível e respeitâvel a discussão pública de questões éticas.

$O$ autor passa então a um estudo dedicado à Moralidade Convencional e ao Relativismo Ético, abordando o relativismo cultural, relativismo ético normativo e absolutismo moral. Em seguida apresenta técnicas de argumentação moral e resolução de problemas morais, analisando detalhadamente as duas abordagens gerais, a utilitarista (uma ação é certa se produz a maior quantidade de bem para o maiot número de pessoas) e a deontológica (as açôes são moralmente certas ou erradas, independente- mente de suas consequências). Concluindo essa parte do livro, o autor explora o status moral das corporaçōes e das organizaçöes formais.

$\mathrm{Na}$ parte denominada Assuntos Morais nos Negócios, ele apresenta um panorama abrangente e detalhado de questóes éticas em praticamente todas as áreas dos negócios. Nessa parte, pretende demonstrar na prática a argumentação ética à qual se referiu na segunda parte do livro. Começando com temas sobre justiça e sistemas econômicos, análise ética do capitalismo, ele passa por questoes tais como marketing e verdade na publicidade, finanças, contabilidade, reestruturaçăo organizacional, computaçắo, direitos dos trabalhadores, discriminação racial, profissionalismo na administração, sistema de negócios internacionais com as empresas multinacionais, diversidades culturais e um tema ao qual ele apropriadamente dá muita ênfase: a questão do meio ambiente e dos recursos naturais.

De George conclui o livro dizendo que estamos presenciando uma mudança na missão dos negócios. O Mito da Amoralidade nos Negócios está em decadência. As decisões das empresas devem passar hoje em dia por muito mais análises do que simplesmente financeiras: as empresas devem levar em conta, alem dos acionistas, selis trabalhadores, os consumidores, a sociedade em geral e o meio ambiente. E para que isto aconteça de forma moral, é necessário que as empresas desenvolvam estruturas que apóiem a ação moral. Essa é a mensagem principal do autor.

Aos pesquisadores da ărea, uma sugestão de estudo: fazer um paralelo para o Brasil de algumas questoes levantadas, tais como o sistema de valores brasileiros, uma análise da moralidade no sistema econômico brasileiro, os principais incidentes éticos das empresas brasileiras, entre outros.

Seu objetivo geral, com suas próprias palavras: "American business can be made more moral". Com as técnicas de argumentação moral e reflexão a respeito das estruturas das empresas, o autor tem uma atitude otimista de que os negócios americanos podem ser mais morais. Um otimismo, entretanto, solidamente argumentado com embasamento acadêmico-teórico, sem cair na ingenuidade. Tal otimismo é sempre agradável e bem-vindo, podendo até ser estendido para os negócios do mundo inteiro, incluindo o Brasil. 